$\mathrm{T}$ HERE ARE MANY EXCITING HAPPENINGS TO report in this issue of the Journal, but pride of place must go to the long-awaited news that we have been accepted for citation in Index Medicus/MEDLINE! We have been working for quite some time to achieve this accolade, which is generally perceived as the Blue Riband of citation indexes. There are many aspects taken into consideration by the Committee of the Library of Congress which determines which Journals are to be accepted. The quality of production is important, as is the acknowledged International Stature of the Editorial Board. Most important, however, is the quality of the published papers. Our acceptance, therefore, owes as much, if not more, to the authors who have submitted material to us as it does to the referees who have assessed their scientific rating. As the editorial and production team, our thanks go to all who have contributed to this success. Having already achieved acceptance for indexing in Current Contents, Research Alert, and Sci Search, we are now well on the way to the next goal, namely achievement of a significant Impact Factor. This will mean that we must continue to publish topical and excellent work, and do so in timely fashion, since the impact of a Journal depends on how many times its own papers are subsequently cited. We continue, therefore, to need your support, and to be sent your best papers. We also need, self-evidently, to ensure that the material published is worthy of further citation.

The second piece of good news is that this is our final quarterly issues. Commencing with the January issue of Volume 9, we will publish six issues each year, with subsequent issues appearing in March, May, July, September and November. Already we have ensured that our publishing schedules will mean that each issue hits your desk at the beginning of the appropriate month, if not even earlier. The advent of bimonthly publication means that we will be able to publish articles more rapidly, certainly within six months of acceptance for publication. This may still prove difficult for some case reports, which we receive in great abundance! We are hesitant to reject interesting reports simply because of pressure of space. Authors of case reports do tend to be more patient than those of original studies, which must continue to be our priority, but we may need to continue to rely on this patience.

As editors and publishers, we are delighted with the quality of all the articles published in this issue, which we believe to give a representative view of the truly international nature of Cardiology in the Young. We are particularly pleased to continue our association with the Association for European Paediatric Cardiology. As reported by their officers, the Annual Meeting in Dublin was a huge success. Those of us present at the meeting can only endorse the views of the officers. It truly was a meeting not only of high scientific quality, but amazingly good social hospitality. Bob Freedom's presentation on Oscar Wilde will remain a vivid memory for all those who were able to squeeze into the packed room at Trinity College. Our pages offer a more tangible souvenir of the meeting, with publication of the abstracts in our Supplement, the Mannheimer lecture by Elliot Shinebourne on pages $428-436$, and the report of the Officers, together with the opening speech of Mary McAleese, on pages 552-554. This Annual meeting of the European Association must now take its place as perhaps the most convivial of the annual meetings discussing matters of significance to those dealing with children with heart disease. We are sure that the Vladimir Pilossof and his committee organising next year's meeting, to be held in Sofia from May 19 through 22, will be eager to beat the record of attendance set at Dublin. We wish them every success.

Robert H. Anderson G. William Henry Geoffrey L. Nuttall 


\section{Acknowledgement to reviewers}

In addition to the members of the Editorial Board, we are greatly indebted to the following reviewers who gave freely of their time and expertise in eval- uating the papers submitted to the Journal. We could not maintain our high standards without their continuing support, and we thank them all.
Dr Dan Penny, London

Dr Ian Huggon, London

Dr Denise Kitchiner, Liverpool

Dr Julene Carvalho, London

Dr Christopher Wren, Newcastle

Dr Renate Kaulitz, Hannover

Prof Adriana

Gittenberger-de Groot, Leiden

Dr Robert Arnold, Liverpool

Dr Oliver Stumper, Birmingham

Dr Shakeel Qureshi, London

Dr Frances Bu'Lock, Liverpool

Dr Carlos Alva, Mexico City

Dr Alison Hayes, Bristol
Dr John Gibbs, Leeds

Dr Michael Burch, Oxford

Dr Michael Gatzoulis, Toronto

Prof Michael Vogel, Berlin

Dr Helena Gardiner, London

Dr Doff McElhinney, Pbiladelphia

Dr François Lacourt-Gayet, Le Plessis Robinson

Dr Atsuko Suzuki, Tokyo

Dr William Neches, Pittsburgh

Dr Jerónimo Farré, Madrid

Dr Victor Grech, Malta

Prof Milan Samanek, Prague

Dr Stewart Hunter, Newcastle
Dr Ian Sullivan, London

Dr Marlene Rabinovitch, Toronto

Dr David Dickinson, Leeds

$\mathrm{Mr}$ Christopher Lincoln, London

Dr Gurleen Sharland, London

Dr Stanley Goldberg, Tucson

Mr Leslie Hamilton, Newcastle

Dr Graham Stuart, Cardiff

Prof $\mathrm{H}$ Singer, Erlangen

Dr W G Williams, Toronto

Dr Charlotte Ferencz, Baltimore

Dr Jia Li, London 